\title{
Selection of dairy cattle for mastitis resistance by somatic milk cells as a system of biological protection against lacteous gland diseases
}

\author{
Anatoly Bolgov ${ }^{1, *}$, Irina Komlyk ${ }^{1}$, and Natalia Grishina ${ }^{1}$ \\ ${ }^{1}$ Petrozavodsk State University, Institute of Biology, Ecology and Agricultural technologies, 185910 \\ Lenin str. 33, Petrozavodsk, Russia
}

\begin{abstract}
The problems of methodology and organization of selection of dairy cattle for resistance to mastitis by somatic cells of milk were studied. The necessity is justified and the procedure for converting the number of somatic cells (NSC) into a points score (PSNSC) is presented. The article provides evidence of the correspondence of the cows distribution curve by points for NSC to the Gauss curve, which is a sufficient reason to consider the NSC points score as a biometrically correct objective selection trait. Procedures for determining the indices of breeding value of bulls and their breeding categories by somatic cells in points are proposed. Requirements for the level of resistance in the cows and bulls selection are developed. The most resistant to mastitis are cows with a score of 3.9 points or less, and bulls with a breeding value index of -1.012 or less.
\end{abstract}

\section{Introduction}

In recent years, the role of genetic factors in reducing the frequency of mastitis (udder inflammation) in cows, a widespread and dangerous disease, has been actively investigated [1-4]. When organizing the screening and selection of dairy cattle for mastitis resistance, the frequency of the disease in herds and populations is considered, as well as an indirect sign associated with mastitis - the number of somatic cells in milk (NSC) [5-7]. An increase in NSC causes an increase in the frequency and severity of udder inflammation, and a decrease in NSC reduces the risk of mastitis. Genetic conditionality of NCS in milk has been proved [8]. The hereditary character of this trait is confirmed, first of all, by the differences between different breeds of dairy cattle. In particular, Ayrshire cows have been shown to have higher resistance to mastitis and a low level of somatic cells in their milk. In the United States, among the 6 dairy breeds, Ayrshires have the lowest linear NSC score 2.69, which indicates their higher resistance to mastitis. In Finland, Ayrshires have less NSC in milk than Holsteins - 164 against 187 thousand $/ \mathrm{cm}^{3}$ [9].

The genetic correlation between somatic cells and mastitis (0.6-0.8) is quite high [8.10], so the genetic evaluation of animals for NSC can be extrapolated to the genetic evaluation for mastitis. In many countries, measures to increase the resistance of dairy cattle to

\footnotetext{
${ }^{*}$ Corresponding author: bolg@petrsu.ru
} 
mastitis are based on the use of indirect and index selection methods with the inclusion of health signs [11-14]. For example, in Finland, the share of such characteristics as udder quality and mastitis resistance in the index of breeding value of animals is the highest $13 \%$ [9].

In the absence of index selection programs in Russia, it is important to develop methods for selecting cows and bulls for mastitis resistance based on somatic milk cells.

The objective of our research is to study ways to use the indicator of the number of somatic cells in milk as a selection method for increasing the resistance of dairy cattle to mastitis.

\section{Materials and methods}

For 3 years, the breeding plant "Megrega" of the Republic of Karelia monthly examined the milk of Ayrshire cows for the content of somatic cells. The method of infrared spectrometry on Bantly equipment was used.

The farm uses pasture-free loose keeping of cows in a highly mechanized dairy complex using a lactary and a Europarallel installation. The productivity of cows during lactation was more than 8 thousand $\mathrm{kg}$ of milk.

About 25 thousand individual samples of cow's milk were tested. To give the trait the properties of a normal distribution, the number of somatic cells (NSC) in milk in thousand $/ \mathrm{cm}^{3}$ was transformed into point score (PSNSC) based on the binary logarithm and the recommended formula [15]:

$$
P S N S C=\log _{2}(N S C / 100000)+3
$$

The bull breeding value index (BVI) was calculated using the generally accepted formula:

$$
B V I=2 *(D-P) * b
$$

BVI - index of breeding value of bulls by the logarithmic number of somatic cells in milk, point; D -logarithm of NSC in bull's daughters, point; P - logarithm of NSC in cows of the population, point; $\mathrm{b}$ - coefficient of repeatability (regression) of indicators of younger bull's daughters on older ones.

\section{Results and discussion}

Many factors influence the NSC in milk: feeding conditions of cows, their breed, individual characteristics, age and resistance of the body, conditions of housing and milking, productivity level, lactation period, season, bacterial contamination of udder and milk, and others. A very high coefficient of NSC variability was established $-\mathrm{C}_{\mathrm{v}}=309.7 \%$. Statistical verification of the distribution of cows by the NSC presented on the histogram (Fig.1) showed that its parameters do not correspond to the null hypothesis and do not obey the normal law. This prevents the use of NSC in milk as a trait in breeding for mastitis resistance. To use the NSC indicator as a selection trait, it must have certain properties have moderate variability, show uniformity of variance in different samples, and meet the requirements of a normal distribution. 


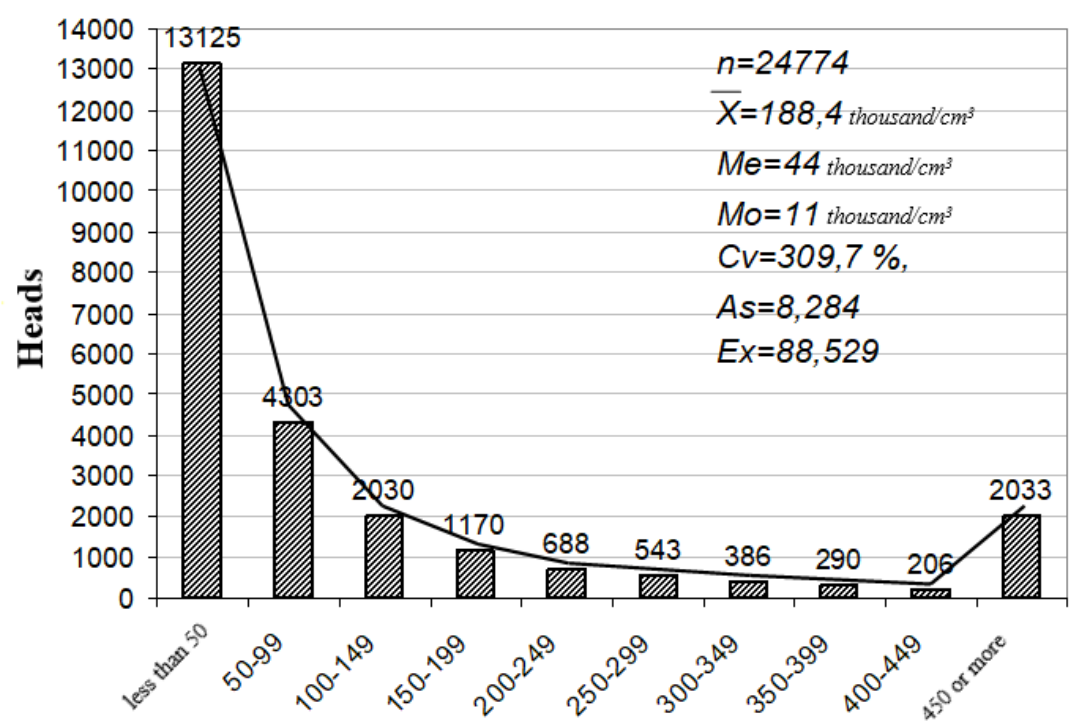

Absolute number of somatic cells, thousand $/ \mathrm{cm}^{3}$

Fig. 1. Histogram of cow distribution by NSC in milk

Converting the number of somatic cells (NSC) to normal distribution scale.

The NSC transformation into points using the formula presented above made it possible to reduce the variability of the trait and obtain a distribution close to the normal one and the Gauss curve (Fig.2). This is a sufficient reason and considers the NSC point score as a biometrically correct objective selection trait suitable for use in scientific and practical breeding. In particular, the CSC score can be used to develop parameters for evaluating and selecting cows for mastitis resistance.

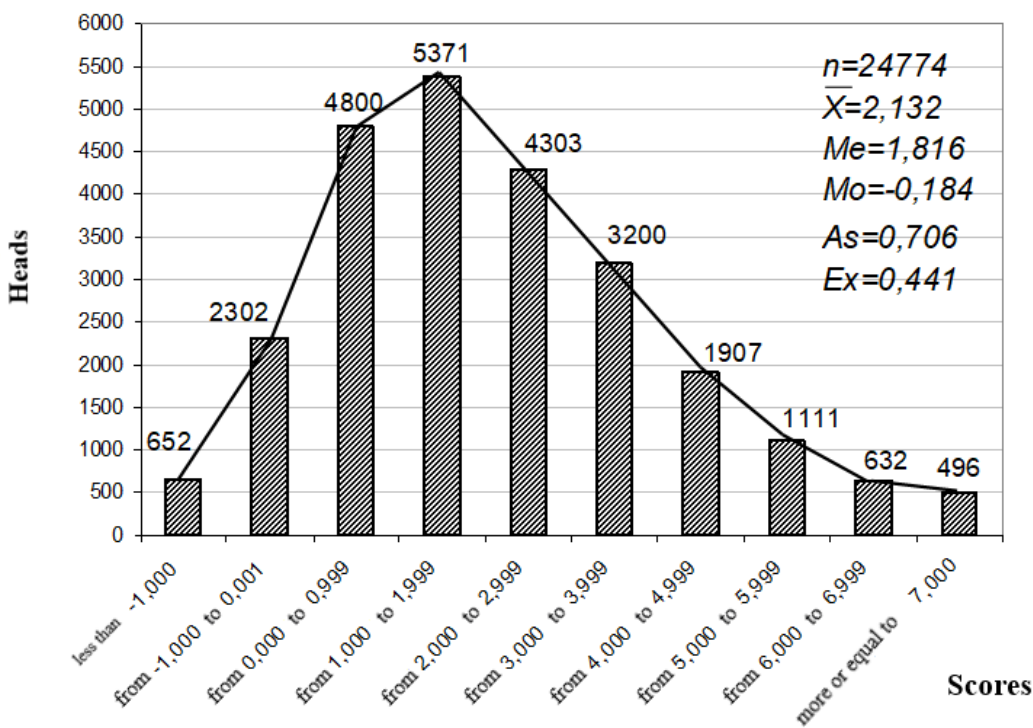

Fig. 2. Histogram of cows distribution according to point score of somatic cells in milk (PS NSC, logarithm of NSC) 
Evaluation and selection of cows for resistance to mastitis based on points for NSC.

The procedure is based on using the developed parameters for cows evaluation and selection (table 1).

Table 1. Parameters of cows evaluation and selection for mastitis resistance based on point score for NSC in milk

\begin{tabular}{|c|c|c|}
\hline $\begin{array}{l}\text { Graduation by } \\
\text { NSC, } \\
\text { thousand } / \mathrm{cm}^{3}\end{array}$ & Score for NSC & Evaluation of resistance and variants of cow use \\
\hline 100 or less & 3.9 or less & highly resistant, unlimited use \\
\hline 200 & $4.0-4.9$ & normal resistance, use as part of the breeding core \\
\hline 400 & $5.0-5.9$ & $\begin{array}{l}\text { lower-than-average resistance, use in the commercial part } \\
\text { of the herd }\end{array}$ \\
\hline 800 or more & 6.0 or more & $\begin{array}{l}\text { low resistance, with repeatability of negative evaluations } \\
\text { are subject to culling }\end{array}$ \\
\hline
\end{tabular}

Cows with a score of 3.9 points or less have the status of highly resistant and are used without restrictions, with a score of 6.0 points or more have low resistance and are subject to culling.

Selection of bulls based on mastitis resistance based on breeding value indices with a score of NSC. 36 bulls were evaluated, each of which accounted for an average of 676 measurements of NSC in the milk of first-calf daughters. Each bull has an index of breeding value (BVI) based on a score for NSC.

NSC point score for the daughters of different bulls. The specificity of the evaluation was the fact that selection to reduce the proportion of individuals with mastitis will lead to a decrease in the value of the estimated indicators (points). Therefore, the best bulls were considered to have a minimum score for NSC and a negative value of the breeding value index, according to the formula.

The offspring of different producers differed greatly in the score for NSC - from 1.26 (best bull) to 3.79 (worst bull, $\mathrm{P}<0.001$ ), which indicates a significant influence of paternal inheritance on the NSC level in the milk of daughters. The coefficient of heritability of the NSC score calculated by the dispersion method was quite pronounced and highly reliable $\left(\mathrm{h}^{2}=0.127, \mathrm{P}<0.001\right)$. This level of genetic diversity between bulls makes it possible to select the best among them and eliminate the worst.

Index of breeding value (BVI) of bulls by NSC score and selection parameters.

The estimated bulls differed greatly in the calculated BVI. The top three producers had a BVI less than minus one $(-1.07 ;-1.21 ;-1.45)$, and the three worst - more than plus two $(2.05 ; 2.25 ; 2.47)$. The evaluated bulls were divided into five breeding categories (table 2$)$ : neutral (BVI within \pm 0.3 of sigma of the population average), the most effective improvers of the 1 st category ( $-1 \sigma$ and more), improvers of the 2 nd category (from $-0.4 \sigma$ to $-0.9 \sigma$ ), degraders (from $+0.4 \sigma$ to $+0.9 \sigma$ ), extreme degraders ( $+1 \sigma$ and more).

Table 2. Parameters of bulls selection for mastitis resistance based on the breeding value index with point score NSC

\begin{tabular}{|c|c|c|}
\hline $\begin{array}{c}\text { Breeding } \\
\text { categories of } \\
\text { bulls }\end{array}$ & $\begin{array}{c}\text { Requirements to BVI } \\
\text { value, score }\end{array}$ & Variant of evaluated bulls use \\
\hline $\begin{array}{c}1 \text { category } \\
\text { improver }\end{array}$ & -1.012 or less & without limitation \\
\hline $\begin{array}{c}2 \text { category } \\
\text { improver }\end{array}$ & from -0.227 to -1.011 & $\begin{array}{c}\text { in addition to the status of "bull father" } \\
\text { and breeding plants }\end{array}$ \\
\hline Neutral & from -0.226 to +0.211 & allowed in product groups and herds \\
\hline
\end{tabular}




\begin{tabular}{|c|c|c|}
\hline Degrader & from +0.212 to +1.101 & $\begin{array}{c}\text { culling with a neutral and low } \\
\text { productivity rating }\end{array}$ \\
\hline $\begin{array}{c}\text { Extreme } \\
\text { degrader }\end{array}$ & +1.102 or more & culling \\
\hline
\end{tabular}

The proposed selection parameters can ensure its objectivity and reasonable use of bulls, increase the accuracy of selection of producers for resistance to udder inflammation, and increase the concentration of mastitis resistance genes.

\section{Conclusion}

The presented methods of evaluation and selection of cows and bulls for mastitis resistance, as elements of their biological protection system, can provide a real increase in the level of livestock health and reduce the incidence of udder diseases, reduce the use of medications, improve the quality of milk, dairy products, and the economic efficiency of cattle breeding.

\section{References}

1. M. Stevens, S. Piepers, S. De Vliegher, J. Dairy Sci. V. 99(4), 2896-2903 (2016)

2. Arash Chegini, Navid Ghavi Hossein-Zadeh, Hossein Hosseini-Moghadam, Acta Sci.Anim. Sci.V., 38 (2),191-196 (2016)

3. K.J. Hand, A. Godkin, D.F. Kelton, J. Dairy Sci. V., 95(3), 1358-1362 (2012)

4. Juliano L. Goncalves, Roger I. Cue, Bruno G. Botaro, Jose A.Horst, Altair A.Valloto, Marcos V. Santos, J. Dairy Sci. V., 101(5), 4357-4366 (2018)

5. Mohanned Naif Alhussien, Ajay Kumar Dang, Vet World, 11(5), 562-577 (2018)

6. Inge-Marie Petzer, Joanne Karzis, Edward F. Donkin, Edward C. Webb, Eric Marcel, Charles Etter, Onderstepoort J. Vet Res, 84(1), 1269 (2017)

7. M Koivula, E A Mäntysaari, E Negussie, T Serenius. J. Dairy Sci. V., 88(2), 827-33 (2005)

8. J. Pösö, World Ayrshire Congress, Finland, Seminar 2, 2 (2008)

9. Finnish Animal Breeding Association (FABA),URL:http://www.faba.fi

10. Kent A.Weigel, George E.Shook, Vet. Clin. Food Anim, 34(3), 457-472 (2018)

11. J. Ødegard, G. Klemetsdal, B. Heringstad, J. Dairy Sci. V., 86(12), 4129-4136 (2003)

12. D. Jattawa, S. Koonawootrittriron, M. A. Elzo, T. Suwanasopee, Asian-Australas J. Anim Sci. V., 25(9), 1216-1222 (2012)

13. M. Alam, C. I. Cho, T. J. Choi, B. Park, J. G. Choi, Y. H. Choy, S. S. Lee, K. H. Cho, Asian-Australas J. Anim. Sci. V., 28(3), 303-310 (2015)

14. A Sewalem, F Miglior, G J Kistemaker, P Sullivan, B J Van Doormaal, J. Dairy Sci. V. 89(9), 3609-3614 (2006)

15. A.K.A. Ali, G. E. Shook, J. Dairy Sci. V. 63(3), 487-490 (1980) 